published catalogue enumerates some 3,650 items ("Verzeichnis der periodischen Schriften der Bibliothek der Kaiserlich Leopoldinisch-Carolinisch Deutschen Akademie der Naturforscher, Halle (Saale)", 1937). The most important work of the Leopoldine Academy has been the publication of a journal, Miscellanea curiosa medico-physica Academice naturce curiosorum sive Ephemerides Germanica, started in 1670 and probably the oldest scientific periodical. In the eighteenth century this valuable journal changed its name to Acta physico-medica and then to Nova acta; in 1932 a new series, Nova Acta Leopoldina, was started.

Various scientific funds have been lost as the result of economic upheaval, but a bequest by Christian Andreas Cothenius, the physician of Frederick the Great, is still operative ; in accordance with it, a medal is from time to time awarded for scientific research. A second medal and a research fund was more recently instituted in memory of Auguste Henri Forel, the biologist and sociologist.

It will be seen from the above account that in modern times the Cæsareo-Leopoldina has received no official protection, nor been subject to governmental control. It is one of the oldest of scientific societies; the Royal Society has indeed the older charter, the Lincei Academy the longer history, albeit not so continuous. The present year is the two hundred and fiftieth after the granting of privileges by Leopold $\mathrm{I}$, and this anniversary was celebrated at Halle on May 28-30. The commemoration was attended by representatives of numerous universities, academies and societies, both German and foreign, who were welcomed in the aula of the University by Prof. E. Abder- halden, the president of the Academy, who has done much to stimulate its activities. His opening address, a historical retrospect, was followed by official congratulations from the rector of the University and the mayor of the city. Then came brief speeches on behalf of the Royal Society of London, the Accademia delle Scienze of Bologna, the Accademia dei Lincei of Rome, the Academies of Vienna, Amsterdam, Copenhagen, Tokyo, the American Academy of Arts and Sciences, at Boston, the Kartell of the German Academies (Berlin, Göttingen, Munich, Leipzig, Heidelberg), etc. It was announced that a sum of 44,000 marks had been collected from numerous donors, to be used henceforth as a research fund.

A very noteworthy lecture was then delivered by Prof. Hans Spemann, of Freiburg, on his recent researches concerning the nature of animal development. Finally, the Cothenius medal, referred to above, was awarded to Profs. Dante de Blasi (Rome), Ostertag (Tübingen), Franz Volhard (Frankfurt), G. Barger (Edinburgh), Max le Blane (Leipzig), Armin Tschermak-Seysenegg (Prague) and Eugen Fischer (Berlin). In the evening there was a banquet with a few speeches. Next day further lectures were given; there was an admirable performance of an operetta in the municipal theatre, and a pleasantly informal reception by the Oberbürgermeister; the third day, a Sunday, was devoted to an excursion in the country.

In connexion with this very successful celebration, there have been printed the above-quoted catalogue of periodicals in the Academy's library, and a well-illustrated Festgabe containing three historical essays and Prof. Spemann's lecture.

\title{
International Agreement for the Regulation of Whaling
}

\section{$\mathrm{T}$}

HE International Agreement for the Regulation of Whaling, which was published on June 23, marks an important stage in the development of whaling regulation. It was the work of a conference at which eleven Governments interested in whaling participated. They met on May 24, and sat almost daily until June 8, when the Agreement was signed. The drastic nature of its provisions are eloquent of the practically world-wide conviction that whaling can be saved from collapse only if it is rationally regulated: while a note under the title "Final Act", which is appended to the Agreement, indicates that the possibility is recognized that actual restriction of whaling effort may prove necessary if that end is to be achieved.

In the early stages of modern antarctic whaling, the scale on which destruction of the whale stock was wrought made the need of regulation apparent. The Falkland Islands Government, which controlled practically all antarctic land stations, gradually built up a system of regulations and-a feature not yet attempted for whaling as a whole, restriction of the number of whaling vesselswhich, while provisional in character owing to lack of information, may be said to have proved adequate until the late 'twenties, when the building of ships eapable of working up the whales 
on the high seas took the main body of whaling into international waters. The Norwegian Whaling Law of 1929 imposed on Norwegian whaling the provisions of the Falklands regulations except limitation, and added the power to prohibit Norwegian whaling in tropical and subtropical waters.

The Geneva Convention of 1931 followed the lines of the Norwegian law, though without provision for elosing areas to whaling. This convention expressed the maximum to which at the time general agreement could be secured. It was recognized that whaling, being mainly outside territorial waters, could be dealt with only by common action, and the inauguration of international treatment was the first object to be attained. The majority of whaling countries adhered to it, and put its provisions into force by legislation which, with the increase of knowledge, tended to go farther and to be more definite than the convention it implemented. Limitation of production was effected by agreements within the industry in several recent seasons: but from various causes these agreements became increasingly difficult to reach, and the International Conference accordingly became necessary.

Space will not permit of any detailed account of the measures taken so far, but it will be useful to summarize the position in the antarctic when the Conference opened, among the countries adhering to the Convention. Only baleen (whalebone) whales were dealt with. Among these Right whales (Balcena glacialis), the numbers of which had been reduced almost to disappearance, were protected completely. Protection of other species was partial. It was illegal to kill immature whales, or cow whales with calves, and lengths were laid down below which for the purposes of the regulation Blue (Balcenoptera musculus) and Fin (B. physalus) whales were to be considered immature. The number of whales killed to afford a given quantity of oil was kept as low as possible by requiring the utmost practicable utilization of each carcass. The pay of gunners had not to depend merely on the number of whales shot. Full records had to be kept of the whales killed and the oil produced. Other provisions, such as the partial protection of the Humpback (Megaptera nodosa) in the Falkland Islands Dependencies, were to be found in certain cases.

The agreement now reached affords complete protection to the Grey whale, Rhachianactes glaucus, as well as to all Right whales. The lengths below which Blue and Fin whales may not be taken is advanced from $60 \mathrm{ft}$. to $70 \mathrm{ft}$. and from $50 \mathrm{ft}$. to $55 \mathrm{ft}$. respectively. The mean size of these species in the antarctic at first maturity was determined in the "Discovery" Investigations as
$74 \mathrm{ft} .2 \mathrm{in}$. for male and $77 \mathrm{ft} .9$ in. for female Blue whales, and $63 \mathrm{ft} .8 \mathrm{in}$. for male and $65 \mathrm{ft} .7 \mathrm{in}$. for female Fin whales. The new limit is thus a marked approach towards the actual mean size at maturity. For the first time, minimal size limits were laid down also for Humpback and Sperm whales (Physeter catodon); namely, $35 \mathrm{ft}$. in each case, this length having a similar relation to the size at first maturity of Humpback and male Sperm whales, according to the best available information and protecting female Sperm whales. Those familiar with the sizes of the whales taken in commercial operations will realize the large body of whales these limits will preserve to reproductive size. It may be noted also that the limits will apply to shore stations.

The seasons for whaling are restricted. Antarctic whaling, that is, whaling south of $40^{\circ} \mathrm{S}$., will take place only from December 8 until March 7, though there is a short extension for next season only; and no shore station may operate for more than six months in the year.

Lastly, pelagic whaling is prohibited over enormous tracts of sea. The whole Atlantic and Indian Oceans north of lat. $40^{\circ} \mathrm{S}$. are closed to it. as is an extensive equatorial belt of the Pacific, The objects of this provision are the protection of calving grounds and the prevention of the destruction of whales when in their least productive condition. It may be possible in the light of further information more narrowly to define these areas, but their present extent guarantees a valuable protection.

The requirements of furnishing statistics and the regulations as to the payment of gunners are as in the previous practice of Norway and Great Britain.

The Agreement is for the coming season only, but there is provision for its year-to-year extension. It has been signed for the Union of South Africa, the United States of America, the Commonwealth of Australia, Germany, the United Kingdom of Great Britain and Northern Ireland and the Dominions, etc., the Irish Free State, New Zealand and Norway. It is to be hoped that other States will adhere to the Agreement : in particular, the adhesion of Japan would make its operation almost world-wide. The "Final Act" appended to the Agreement shows that the possible desirability of changes and extensions of its terms is fully recognized, and it is recommended indeed that next year, after the experience of a season's working, another conference should be convened to consider the Agreement in these respects. A very welcome recommendation is that Governments should take powers to regulate the methods of killing whales. There is reason to think that this would be in the interests of both economic working and humanitarianism.
J. O. B. 